\title{
Research Articie: Diallel analysis in greengram [Vigna radiata (L.) Wilczek]
}

Article Chronicle: Received : 19.07.2017; Accepted : 03.08.2017

\section{KeY WoRDS:}

Greengram, Half diallel analysis, $g c a$, sca, Yield components

Author for correspondence :

\section{SWARNA LATHA}

Department of Genetics and Plant Breeding, College of Agriculture, Professor Jayashankar Telangana State Agricultural University, Rajendranagar, HYDERABAD (TELANGANA) INDIA Email :

vswarnalatha1980@ rediffmail.com

See end of the article for authors' affiliations

\section{SWARNA LATHA, K.B. ESWARI AND S. SUDHEER KUMAR}

SUMMARY : Nine diverse greengram parents were selected and crossed in half diallel fashion in order to determine combining ability to identify promising hybrids for twelve traits including yield and its components. Analysis of variance for general and specific combining ability revealed that $g c a$ and $s c a$ variances were significant for all the characters. Whereas, comparison of the estimates of variances due to specific combining ability were higher than general combining ability for all the traits except plant height and pods per plant pointed out to be the preponderance of non-additive gene effects in the expression of these characters. Among the parents MGG-347 was proved to be a good general combiner for five characters viz., number of primary branches per plant,number of clusters/plant, number of pods per plant, number of seeds/pod and seed yield per plant and WGG-42 showed best gca effect for days to $50 \%$ flowering, days to maturity, 100 seed weight and seed yield per plant. While, K-851 was good general combiner for number of primary branches per plant, number of clusters/plant, number of pods per plant, seed yield per plant and protein content followed by KM 11-564 for number of clusters/ plant, number of pods per plant, pod length, number of seed per pod and harvest index. Among the crosses MGG-347 X KM 11-564 was best specific combination for seed yield per plant as well as number of pods per plant, number of branches per plant, 100 seed weight, harvest index and protein content.It is evident from present investigation that the hybrid combinations WGG-42 $\times$ RM 12-13, MGG-347× RM12-13, LGG-543 × KM 11-564and MGG-347 × LGG-543 exhibited the high per se performance and $s c a$ effect for seed yield per plant and highly promising even in respect of other characters could be advanced by selecting desirable segregants and recombinants in each generation for funneling the new genotype or for using further advanced breeding programme.

How to cite this article : Latha, V. Swarna, Eswari, K.B. and Kumar, S. Sudheer (2017). Diallel analysis in greengram [Vigna radiata (L.) Wilczek]. Agric. Update, 12(TECHSEAR-7) : 1817-1821; DOI: 10.15740/HAS/ AU/12.TECHSEAR(7)2017/1817-1821. 